Jurnal Interpretasi Hukum | ISSN: 2746-5047

Vol. 2, No. 3-Desember 2021, Hal. 584-589| Tersedia online di

https://www.ejournal.warmadewa.ac.id/index.php/juinhum

DOI: https://doi.org/10.22225/juinhum.2.3.4141.584-589

\title{
KEDUDUKAN BADAN PERMUSYAWARATAN DESA (BPD) SEBAGAI LEMBAGA PENGAWAS TERHADAP KINERJA KEPALA DESA DI DALAM PEMERINTAHAN DESA
}

\author{
I Gusti Made Bayu Nugraha, I Gusti Bagus Suryawan, I Wayan Arthanaya \\ Fakultas Hukum, Universitas Warmadewa, Denpasar-Bali, Indonesia \\ bayu.nugraaha1998@gmail.com, suryawanmeraku@gmail.com, arthanaya.wayan@gmail.com
}

\begin{abstract}
Abstrak
Pemerintah daerah adalah suatu bentuk pemerintahan yang efisien dan efektif, karena pemerintah pusat tidak dapat menangani semua masalah negara yang kompleks. Permasalahan yang diangkat dalam penelitian ini adalah tentang kewenangan badan permusyawaratan desa sebagai lembaga pengawasan terhadap kinerja kepala desa. Tujuan penelitian ini guna mengkaji kedudukan badan permusyawaratan desa di dalam pemerintahan desa serta pelaksanaan pengawasan BPD terhadap kinerja kepala desa dalam pemerintahan desa. Metode yang digunakan adalah metode penelitian hukum normatif dengan pendekatan kasus. Teknik pengumpulan data dilakukan dengan studi kepustakaan. Adapun sumber bahan hukum yang digunakan yaitu sumber bahan hukum primer, sekunder dan tersier yang kemudian dianalisis secara sistematis. Hasil penelitian menunjukkan bahwa kewenangan dari badan permusyawaratan desa adalah mengadakan pertemuan dengan masyarakat guna mengumpulkan keinginannya, menyalurkan keinginan masyarakat kepada pemerintah desa baik secara lisan dan tertulis, mempresentasikan rancangan perdes yang menjadi kewenangannya, memantau dan mengevaluasi kinerja kepala desa, meminta informasi penyelenggaraan pemerintahan desa kepada pemerintah desa, menyampaikan pendapat atas penyelenggaraan pemerintahan desa, melaksanakan pembangunan desa, memajukan masyarakat desa dan memberdayakan masyarakat desa.
\end{abstract}

Kata Kunci: Badan Permusyawaratan Desa, Kinerja Pemerintah Desa, Lembaga Pengawas

\begin{abstract}
Local government is an efficient and effective form of government, because the central government cannot handle all the complex problems of the state. The problem raised in this study is about the authority of the village consultative body as a supervisory agency for the performance of the village head. The purposes of this study are to examine the position of the village consultative body in the village government and the implementation of BPD supervision on the performance of the village head in the village government. The method used is a normative legal research method with a case approach. The technique of data collection is done by literature study. The sources of legal materials used are primary, secondary and tertiary sources of legal materials which are then analyzed systematically. The results of the study indicate that the authority of the village consultative body is to hold meetings with the community to collect their wishes, channel the wishes of the community to the village government both orally and in writing, present the draft Perdes under its authority, monitor and evaluate the performance of the village head, request information on the administration of village governance to the village head. village government, express opinions on the implementation of village governance, carry out village development, promote village communities and empower village communities.
\end{abstract}

Keywords: Village Consultative Body, Village Government Performance, Supervisory Agency

\section{PENDAHULUAN}

Pemerintahan Daerah (Pemda) merupakan bentuk pemerintahan yang efisien dan efektif karena pemerintah pusat tidak dapat menyelesaikan semua permasalahan negara yang kompleks. Berdasarkan UU No. 23 Tahun 2014 Tentang Pemerintahan Daerah (UU Pemda), Pemda merupakan pelaksana segala urusan pemerintahan oleh Pemda bekerja sama dengan Dewan Perwakilan Rakyat Daerah (DPRD) berdasarkan asas otonomi serta kinerja pembantuan dengan asas otonomi seluas-luasnya dalam sistem pemerintahan Negara Kesatuan Republik Indonesia. Berdasarkan UU Pemda yang termuat dalam poin 4 Perda No. 4 Tahun 2018 Tentang BPD prinsip otonomi daerah menggunakan prinsip otonomi yang seluas-luasnya, dalam artian daerah diberikan kewenangan untuk mengurus dan mengatur urusan pemerintahan diluar dari yang menjadi urusan pemerintah pusat yang ditetapkan dalam UU tersebut. Selain itu penyelenggaraan otonomi daerah diharapkan agar terciptanya 
keserasian hubungan antar daerah dengan daerah lainnya, yang artinya daerah mampu membangun hubungan kerja sama antar daerah untuk meningkatkan kesejahteraan bersama dan mencegah adanya ketimpangan antar daerah.

Di dalam wilayah daerah selain terdapat pemerintahan daerah juga terdapat pemerintahan desa, pemerintahan daerah dan pemerintahan desa adalah pemerintahan yang dimana berdasarkan pada otonomi, yakni pemerintahan daerah didasarkan pada otonomi daerah sedangkan pemerintahan desa berlandaskan akan otonomi desa hubungan antara otonomi daerah dan otonomi desa sangat erat dan sangat berkaitan, hal ini dikarenakan area desa yang ada dalam cakupan area daerah (Widjaja, 2003).

Berdasarkan UU Pemda, yang telah melegalkan keberadaan otonomi desa, yang mana otonomi telah dipunyai oleh desa merupakan otonomi yang berdasarkan silsilah dan juga budayanya dan tidak atas dasar pemberian kuasa dari pemerintah. Terdapat perubahan dalam aspek pemerintahan desa, yakni pemerintahan desa adalah sebagai unsur eksekutif dan Badan Permusyawaratan Desa (BPD) ialah sebagai unsur legislatif di dalam pemerintahan desa, pengaturan mengenai desa di dalam UU Pemda kemudian ditindaklanjuti dengan lahirnya UU No. 6 Tahun 2014 Tentang Desa (UU Desa). Terbentuknya UU Desa berawal dari tahun 2007 hingga tahun 2013 hal itu merupakan suatu perjalanan panjang dalam pembentukannya, RUU Desa pada finalnya dilegalkan dalam bentuk UU Desa pada Sidang Paripurna DPR RI, 18 Desember 2013. UU Desa, menjadikan Desa tidak lagi sebagai obyek pembangunan, akan tetapi menjadi subyek pembangunan. Dalam perjalanannya UU Desa yang tercantum dalam pertimbangan SK Perda Kabupaten Badung No. 4 Tahun 2018 Tentang BPD yang berbunyi bahwa untuk melaksanakan ketentuan Pasal 65 ayat (2) UU Desa dan Pasal 73 ayat (1) Permendagri No. 110 Tahun 2016 tentang BPD perlu menetapkan Perda tentang BPD. Sedangkan UU Desa termuat pada poin 3 yang berbunyi mengingat UU Desa.

Di dalam wilayah daerah selain terdapat pemerintahan daerah juga terdapat pemerintahan desa, pemerintahan daerah dan pemerintahan desa adalah pemerintahan dimana pemerintahan itu berlandaskan atas otonomi, yakni pemerintahan daerah didasarkan pada otonomi daerah sedangkan pemerintahan desa berlandaskan akan otonomi desa hubungan antara otonomi daerah dan otonomi desa sangat erat dan juga melengkapi antara keduanya, hal ini dikarenakan area desa tercakup dalam area daerah. Dan juga berlangsung adanya perevisian mengenai pemerintahan desa, yakni pemerintahan desa ialah sebagai unsur eksekutif dan BPD ialah sebagai unsur legislatif di dalam pemerintahan desa, pengaturan mengenai desa di dalam Perda No. 4 Tahun 2018 Tentang BPD kemudian ditindaklanjuti dengan lahirnya UU Desa. Hal ini ditekankan oleh Wibowo \& Maharani (2019), BPD di Pemerintahan Desa adalah lembaga desa yang memiliki kedudukan sejajar dengan Pemerintah Desa. Layaknya DPR di Pemerintahan Pusat atau DPRD di Pemerintahan Daerah, BPD berdiri sebagai perwujudan demokrasi masyarakat di tingkat desa.

Dari segi kewenangan, pada prinsipnya tidak ada perubahan mendasar dalam peraturan pemerintah desa. Sama halnya dengan peraturan yang terdahulu mengenai desa. UU Desa mengidentifikasi desa atau yang dikenal sebagai kesatuan masyarakat hukum dengan batas-batas wilayah yang berwenang mengatur dan mengurus kepentingan masyarakat desa di wilayah yang bersangkutan, berdasarkan asal-usul dan adat istiadat setempat yang diakui dan dihormati dalam sistem pemerintahan negara kesatuan republik Indonesia. Di dalam perkembangannya terdapat beberapa sudut pandang serta pengertian akan otonomi desa yakni sudut pandang mengenai legal formal yang sering diberikan pengertian dari beberapa para ahli hukum di dalam beberapa UU tentang desa sering ditemukan mengenai pengertian tentang desa yakni, desa adalah kesatuan masyarakat hukum yang mengatur dan mengurus jalannya pemerintahannya sendiri. Sebagai definisi mengenai otonomi desa. Pengertian tentang desa tersebut ialah sebuah subjek hukum yang berhak dan berwenang di dalam membuat suatu tindakan hukum, antara lain membuat surat-surat yang bersifat resmi, berhubungan dengan pengadilan, menjalin kerjasama antar pemerintahan desa dan lain sebagainya namun otonomi bukan sekedar hanya mengenai persoalan hubungan hukum melainkan mengenai berbagai hal yang berhubungan dengan konteks sistem pemerintahan dan hubungan antara desa beserta dengan negara, untuk desa apabila sudah memperoleh pembagian kewenangan dan keuangan dari pemerintah pusat maka baru bisa disebut dengan desa otonomi yang sehingga nantinya desa memiliki sebuah kewenangan untuk mengatur, mengurus dan mengelola jalannya pemerintahan. Otonomi desa dapat dicermati serta dijelaskan bagaikan sebuah wujud yang diakui dari negara kepada kehadiran dan juga keberadaan desa serta dengan hak silsilah dan juga budayanya. Hal ini berarti 
negara tidak akan merusak keberadaan dari desa melainkan negara melindungi dan melestarikan eksistensi keberadaan desa dan negara kemudian harus mengakui dan melindungi keberadaan dari desa yang merupakan keberadaan desa lebih dulu munculnya dibandingkan dengan keberadaan dari negara kesatuan republik indonesia yang dimana nantinya dengan adanya pengakuan ini maka keberadaan dari desa akan tetap ada (Syafirudin \& Na'a, 2010). Desa merupakan bagian terkecil dan terendah di dalam pemerintahan negara republik Indonesia, meskipun terdapat berbagai aturan yang mengatur mengenai otonomi daerah dengan pelimpahan berbagai wewenang pada tingkat daerah maka tidak akan dapat mempengaruhi dari keberadaan desa. Desa merupakan suatu entitas yang otonom yang dapat mengurus dan mengatur urusannya sendiri. Keberadaan dari desa sebagai entitas sosial dan budaya telah lebih dulu ada keberadaannya sebelum kesatuan republik Indonesia terbentuk.

Pelaksanaan hak, kekuasaan, dan kebebasan otonomi desa menuntut tanggung jawab semua pihak untuk menjaga keutuhan, persatuan dan kesatuan bangsa Indonesia serta mewujudkan kesejahteraan rakyat dan peraturan yang berlaku. Dalam Rangka mewujudkan demokrasi di dalam penyelenggaraan pemerintahan desa, maka di bentuklah sebuah badan yang bernama BPD (Abdullah, 2003). BPD ialah perubahan nama yang dulu disebut dengan Badan Perwakilan Desa dan diubah namanya sekarang menjadi BPD dimana perubahan nama tersebut didasarkan pada kondisi faktual bahwa budaya politik lokal yang berbasis pada suatu filosofi "Musyawarah dan Mufakat". Berdasarkan pada hal tersebut musyawarah merupakan sebuah proses di dalam memecahkan suatu masalah sedangkan yang dimaksud dengan mufakat merupakan suatu hasil dari suatu hal yang telah dibahas. Melalui adanya suatu musyawarah dan mufakat diharapkan agar konflik-konflik yang terjadi dalam kehidupan bermasyarakat untuk dapat diselesaikan konflik tersebut dengan bijaksana, sehingga nantinya tidak menimbulkan konflik yang berkepanjangan yang nantinya dapat merugikan masyarakat luas. BPD berfungsi sebagai badan yang menetapkan Perdes bersama dengan Kades, menampung dan menyalurkan aspirasi masyarakat desa dan melakukan pengawasan terhadap kinerja dari Kades. BPD merupakan mitra kerja dari pemerintahan desa yang kedudukannya setara perihal pelaksanaan pemerintahan desa, pembangunan dan pemberdayaan masyarakat desa. BPD memiliki kewenangan untuk menyetujui atau tidak menyetujui kebijakan desa yang dikembangkan oleh pemerintah desa. BPD dapat menulis Perdes dengan pemerintah desa dan disebut Perdes. Maka dalam hal ini akan tercipta sistem check and balance system di dalam pemerintahan desa, sebagai lembaga pengawas BPD mempunyai keharusan di dalam melaksanakan pengawasan pada keputusan dari pemerintahan desa, anggaran dan pendapatan belanja desa (APBDes) dan kinerja dari Kades (Ndraha, 1985). BPD adalah sebuah lembaga perwakilan yang dibentuk dengan tujuan untuk mengawasi kinerja dari pemerintahan desa yakni Kades yang dibantu dengan perangkat desa. BPD merupakan sebuah lembaga sebagai perwujudan demokrasi di dalam pemerintahan desa.

Adapun penelitian terdahulu dari Malik (2020) menjelaskan bahwa BPD di Desa Labuang Kecamatan Namrole Kabupaten Buru Selatan tidak mengerti apa yang harus dilakukan terkait dengan fungsi kontrol dan fungsi pengawasan yang menjadi kewenangannya dalam mengontrol dan mengawasi kinerja pemerintah desa/kepala desa, anggaran operasional BPD sangat minim serta sarana dan prasarana BPD sangat tidak memadai dan tidak memiliki kantor sendiri sehingga dalam menjalankan tugasnya, anggota BPD yang tidak secara aktif mensosialisasikan sebuah peraturan desa. Sedangkan, Junior et al., (2021) memaparkan bahwa Badan Permusyawaratan Desa (BPD) mempunyai fungsi untuk dapat melakukan pemeriksaan terhadap pengaturan finansial desa Desa Blahkiuh dengan pendampingan berkelanjutan. Badan Permusyawaratan Desa (BPD) tidak bekerja dengan sebagaimana mestinya dalam pengawasan pengaturan dana desa di Desa Blahkiuh, hal ini disebabkan oleh partisipasi masyarakat yang rendah, fasilitas operasional BPD yang kurang, subsidi yang tidak mencukupi, kurangnya pelatihan dan konsultasi tentang pengelolaan desa, perencanaan dan pelaksanaan anggaran serta kurangnya koordinasi. Lebih lanjut, Awaeh et al., (2017) memaparkan fungsi dari Badan Permusyawaratan Desa Sereh yakni dengan melakukan evaluasi terhadap pengelolaan administrasi pembangunan yang di lakukan oleh kaur ekonomi pembangunan dan juga menyalurkan aspirasi masyarakat namun tidak diimbangi dengan kinerja pemerintah yang terkesan lamban dalam menindak lanjuti keluhan masyarakat. Dari kasus tersebut maka dilakukannya penelitian yang bertujuan untuk mengkaji kedudukan badan permusyawaratan desa di dalam pemerintahan desa serta pelaksanaan pengawasan BPD terhadap kinerja kepala desa dalam pemerintahan desa. 


\section{METODE PENELITIAN}

Jenis penelitian yang digunakan ialah jenis penelitian hukum normatif dengan pendekatan kasus. Teknik pengumpulan bahan hukum dilakukan dengan teknik studi kepustakaan, maka teknik penghitungan atau penelusuran bahan hukum dalam daftar tersebut dikelompokkan atau dikelompokan, dan digunakan metode kualitatif mencatat, mencatat, mengutip, meringkas, dan meninjau sesuai kebutuhan. Mengenai sumber dokumen hukum yang digunakan terbagi menjadi tiga yaitu sumber hukum primer, sekunder, dan tersier. Sumber bahan hukum primer yang didapat dengan menganalisis peraturan perundang-undangan, risalah resmi, dan beberapa keputusan-keputusan yang menyangkut dengan judul penelitian ini. Sumber hukum sekunder adalah dokumen hukum yang digunakan untuk mendukung atau membantu memberikan pemahaman dan ilustrasi serta teori hukum yang digunakan untuk mengomentari dan menyelesaikan masalah untuk dipertimbangkan dalam proses penulisan penelitian. Bahan Hukum Tersier ialah bahan hukum yang memberikan petunjuk maupun penjelasan terhadap bahan hukum primer dan sekunder. Setelah mengumpulkan semua bahan hukum, selanjutnya akan menggunakan metode pengolahan bahan hukum yang sistematis untuk pengolahan serta analisisnya.

\section{HASIL DAN PEMBAHASAN}

\section{Kedudukan Badan Permusyawaratan Desa di Dalam Pemerintahan Desa}

Kedudukan dari BPD adalah sebagai lembaga penyelenggara pemerintahan desa di dalam pemerintahan desa. Dengan terbentuknya BPD yang merupakan terjadinya sebuah faktor historis atas dominasi yang kuat oleh pemerintahan desa dalam penyelenggaraan pemerintahan desa, di dalam hal mengintervensi dinamika sosial politik yang terjadi di dalam pemerintahan desa (Dwipayana, 2003), maka atas dasar dari dinamika tersebut maka munculah sebuah lembaga yang bernama BPD yang diharapkan keberadaannya di dalam pemerintahan desa sebagai sebuah lembaga yang memiliki kekuatan sebagai lembaga penyeimbang dan sebagai lembaga legislatif desa atas dominasi yang diciptakan oleh pemerintah desa. Terbentuknya BPD di dalam pemerintahan desa yakni terbentuk pada tahun 2014 dengan diberlakukannya UU Pemda yang menyebutkan bahwa Kedudukan dari BPD merupakan sebagai lembaga pemerintahan desa.

Terbentuknya UU Desa berawal dari tahun 2007 hingga tahun 2013 hal itu merupakan suatu perjalanan panjang dalam pembentukannya, RUU Desa pada finalnya dilegalkan dalam bentuk UU Desa pada Sidang Paripurna DPR RI, 18 Desember 2013. UU Desa, menjadikan Desa tidak lagi sebagai obyek pembangunan, akan tetapi menjadi subyek pembangunan. Fungsi yang dimiliki oleh BPD sebagai lembaga legislatif desa di dalam pemerintahan desa kemudian diganti dengan UU Pemda, yang menyebutkan bahwa BPD menjadi kelengkapan dari pemerintah desa. Dimana sebagai bagian dari pemerintahan desa BPD berwenang untuk turut ikut serta di dalam hal mengatur dan mengurus jalannya pemerintahan di dalam pemerintahan desa dan hanya memiliki fungsi sebagai lembaga yang menetapkan Perdes bersama dengan Kades dan menyalurkan aspirasi dari masyarakat desa, hal ini juga diperkuat dengan terbitnya atau dengan adanya PP NRI No. 72 tahun 2005 tentang pemerintahan desa yang mana diperjelas dengan pasal-pasal yang menyatakan bahwa BPD memiliki fungsi didalam pemerintahan desa sebagai lembaga yang menetapkan Perdes bersama dengan Kades dan BPD memiliki tugas yang dimana lembaga yang mewadahi serta mengutarakan keinginankeinginan dari masyarakat desa.

Di dalam UU Desa terdapat perubahan-perubahan mengenai BPD. Perubahan yang terjadi yakni BPD yang dulunya bernama badan perwakilan desa kemudian diganti namanya menjadi BPD, begitu juga di dalam hal pemilihan anggota dari BPD terdapat sebuah perbedaan yang memiliki sebuah dampak yang signifikan terhadap keberadaan dari BPD yakni mengenai calon-calon anggota dari BPD adalah kalangan-kalangan yang diusulkan oleh kalangan adat, kalangan agama, kalangan organisasi sosial politik golongan-golongan profesi dan unsur-unsur di kalangan pemuka desa yang lainnya yang memenuhi persyaratan yang berlaku untuk menjadi anggota dari BPD. Dengan hal ini yang nantinya akan diharapkan tidak akan ada lagi satu bagian pun dari unsur eksekutif dari desa untuk ikut di dalam hal pencalonan untuk menjadi bagian dari anggota BPD, baik dari pihak Kades ataupun perangkat dari pemerintahan desa. Berdasarkan UU Desa Badan Permusyawaratan Desa tidak 
lagi memiliki kewenangan di dalam menetapkan calon terpilih dari Kades yang memperoleh suara terbanyak di dalam pemilihan Kades.

Melihat dari kedudukannya BPD menurut UU Desa BPD memiliki fungsi di dalam membuat kebijakan-kebijakan di dalam pemerintahan desa bersama dengan Kades harus mempunyai sebuah program kerja yang sama antara badan permusyawaratan desa dengan Kades agar tidak ada konflikkonflik di dalam pemerintahan desa agar terciptanya hubungan yang harmonis antara BPD dengan Kades yang nantinya agar terciptanya penyelenggaraan pemerintahan desa yang baik. berdasarkan pada penjelasan tersebut maka dapat dilihat bahwa kedudukan yang dimiliki oleh BPD di dalam pemerintahan desa adalah sejajar dengan pemerintahan desa dan BPD merupakan mitra kerja dari pemerintahan desa di dalam pemerintahan desa (Pramesti, 2013).

\section{Pelaksanaan Pengawasan BPD Terhadap Kinerja Kepala Desa Dalam Pemerintahan Desa}

Saat ini, BPD merupakan sarana penyalur aspirasi sekaligus mewakili para peserta dalam pengambilan kebijakan desa. Peran BPD dibutuhkan guna mengurangi akan terjadinya kepentingan pribadi di Desa. Sebagai badan perwakilan, tidak semua persoalan perlu ditangani di tingkat pemerintahan kabupaten. Sebagai mitra pemerintah desa, BPD merupakan mitra pemerintah desa dalam menjalankan tugas dan fungsinya. Kedudukan sebagai mitra pemerintah desa berarti tidak ada atasan maupun bawahan di antara kedua belah pihak, sehingga peraturan tersebut menyatakan bahwa meskipun kepala desa bertanggung jawab kepada penduduk melalui BPD, BPD tidak dapat langsung diberhentikan dari jabatan desa. kepala. BPD hanya dapat mengusulkan untuk memberhentikan kepala desa melalui perantara bupati, jika tidak kepala desa tidak dapat membubarkan BPD.

Berikut beberapa cara BPD Desa melacak implementasi Perdes, antara lain

a. Memantau setiap tindakan pemerintah desa.

b. Jika ada pelanggaran, BPD akan mengeluarkan first family warning.

c. BPD akan mengklarifikasi pada rapat desa yang dipimpin oleh ketua BPD.

d. Jika tindakan tersebut sulit diselesaikan, BPD akan mengeluarkan sanksi regulasi atau peringatan, seperti laporan ke Camat dan Bupati untuk ditindaklanjuti.

Dengan memahami posisi BPD, diharapkan BPD dapat berperan secara penuh dan proaktif dalam mengawasi pemerintahan desa. Sebagai alat untuk mewujudkan demokrasi pancasila. BPD harus menjalankan fungsi pengawasan penyelenggaraan pemerintahan desa (Syafirudin \& $\mathrm{Na}^{\prime}$ a, 2010). Peran BPD adalah membahas dan menyepakati rancangan Perdes dengan kepala desa, mengakomodir dan membimbing keinginan masyarakat desa, serta mengawasi kinerja kepala desa. Dari ketiga tugas tersebut terlihat bahwa BPD merupakan organisasi yang memiliki kekuasaan menyepakati peraturan desa yang akan menjadi pedoman pelaksanaan pembangunan desa. BPD juga berhak menyampaikan keinginan warganya. Penyampaian pengaduan dilakukan melalui tahapan kerja yang berbeda, yaitu BPD harus memahami keinginan masyarakat, menanggapi keinginan masyarakat yang disampaikan kepada BPD, dan mengelola keinginan masyarakat sebagai energi positif untuk membentuk tahapan kebijakan desa.

BPD juga menyampaikan keinginan warga desa kepada kepala desa, yang kemudian digunakan oleh kepala desa dan jajarannya sebagai pedoman dalam melaksanakan program pembangunan desanya. Secara khusus, BPD juga berhak melakukan pengawasan terhadap pembangunan desa dalam segala aspek. Hal ini menunjukkan betapa kuatnya BDP dalam ranah politik dan sosial desa. Selain itu, BPD juga berhak menyelenggarakan Musyawarah Desa (Musdes) sesuai agenda yang mewajibkan Musdes, salah satunya Musdes, untuk membahas rencana pembentukan Badan Usaha Milik Desa (BUMDes). Tanpa persetujuan BPD, BUMDes tidak bisa mandiri. Pada saat yang sama, BPD merupakan salah satu organisasi yang akan memantau proses yang dilakukan di BUMDes.

\section{SIMPULAN DAN SARAN}

\section{Simpulan}

Kedudukan BPD sebagai lembaga pemerintahan desa mempunyai kedudukan yang sama dalam penyelenggaraan pemerintahan desa, pembangunan dan pemberdayaan masyarakat desa, dengan fungsi sebagai berikut a) menyelenggarakan pengelolaan desa kepada pemerintah desa b) Deklarasi pendapatan untuk perangkat desa, pengembangan masyarakat desa dan pemberdayaan masyarakat 
desa. c) Mengumpulkan biaya operasional untuk melaksanakan tugas dan fungsi Panitia Pengumpulan Anggaran dan Belanja Desa. Pelaksanaan pengawasan BPD terhadap kegiatan kepala desa di lingkungan badan pengelola desa terbagi menjadi dua, lebih khusus lagi (1) Pengawasan internal adalah pengawasan yang dilakukan oleh orang atau badan di desa, unit organisasi yang bersangkutan. Saat ini, (2) Pengawasan eksternal adalah pengawasan oleh unit pemantau yang bertanggung jawab untuk memantau pelaksanaan kepala desa atau organisasi di luar unit yang diawasi. Metode pemantauan yang dilakukan oleh BPD desa terhadap pelaksanaan Perdes antara lain (1) Pemantauan terhadap semua tindakan yang dilakukan oleh pemerintah desa, (2) Jika ada celah, BPD akan mengeluarkan peringatan untuk pertama kali dalam keluarga. cara. (3) BPD akan melakukan klarifikasi dalam rapat desa yang dipimpin oleh ketua BPD. (4) Apabila dilakukan tindakan yang tidak dapat diselesaikan, BPD akan memberikan sanksi atau peringatan sesuai dengan ketentuan, seperti laporan kepada Camat dan Bupati untuk ditindaklanjuti.

\section{Saran}

Kepada BPD dalam menjalankan tugas dan tanggungjawab hendaknya BPD mampu bersinergi atau bekerjasama yang baik dengan aparat desa, serta melaksanakan tugas dan fungsinya sesuai dengan peraturan yang sudah ditetapkan, sehingga masyarakat mendapatkan perhatian di dalam menyalurkan aspirasinya di Desa. Kades diharapkan mampu berkomunikasi dan saling berkoordinasi dengan BPD dalam setiap kegiatan yang dilaksanakan di desa, sehingga terjalinnya kerjasama yang baik dalam mensejahterakan masyarakat dan pembangunan di Desa. Kepada Masyarakat dalam menyampaikan aspirasinya masyarakat diharapkan memberikan masukan-masukan serta usul-usul yang positif terkait dengan kelangsungan pembangunan di Desa sehingga terwujudnya keharmonisan antara masyarakat, Kades dan BPD.

\section{DAFTAR PUSTAKA}

Abdullah, R. (2003). Pelaksanaan Otonomi Luas dengan Pemilihan Kepala Daerah. Rajawali Pers, Jakarta.

Awaeh, S., Kaawoan, J. E., \& Kairupan, J. (2017). Peranan Badan Permusyawaratan Desa (BPD) Dalam Penyelenggaraan Pengawasan Pemerintahan (Studi di Desa Sereh 1 Kecamatan Lirung Kabupaten Talaud). Jurnal Eksekutif, 1(1), 1-11.

Dwipayana, A. A. (2003). Membangun Good Governance di Desa. IRE Pres, Yogyakarta.

Junior, I. K. G. A., Wijaya, I. K. K. A., \& Arthanaya, I. W. (2021). Efektivitas Pengawasan Badan Permusyawaratan Desa (BPD) Terhadap Pengelolaan Dana Desa (Desa Blahkiuh, Kecamatan Abiansemal, Kabupaten Badung). Jurnal Interpretasi Hukum, 2(2), 391-396.

Malik, S. (2020). Peran Badan Permusyawaratan Desa Dalam Penyelenggaraan Pemerintahan Desa. Jurnal Ius Constituendum, 5(2), 325-343.

Ndraha, T. (1985). Pembangunan Desa dan Administrasi Pemerintahan Desa. Yayasan Karya Dharma, Jakarta.

Pramesti, T. J. A. (2013). Kedudukan Kepala Desa Dan Badan Permusyawaratan Desa. Fakultas Hukum Universitas Indonesia.

Syafirudin, A., \& Na'a, S. (2010). Republik Desa. Alumni, Bandung.

Wibowo, F. A., \& Maharani, A. E. P. (2019). Optimalisasi Kinerja Badan Permusyawaratan Desa (BPD) Dalam Pembuatan Produk Hukum Desa Pasca Berlakunya Undang-undang Nomor 6 Tahun 2014 Tentang Desa. Res Publica, 3(3), 327-342.

Widjaja, H. (2003). Otonomi Desa Merupakan Otonomi yang Asli, Bulat dan Utuh. Rajawali Pers, Jakarta. 